\title{
Estimation Of Number And Genes Actions Of Cpmmv (Cowpea Mild Mottle Virus) Disease Resistance Genes On Soybean Crop
}

\author{
Agus Suryanto $^{1}$, Kuswanto $^{2}$, SM. Sitompul ${ }^{2}$, Astanto Kasno ${ }^{3}$ \\ ${ }^{l}$ Graduate Program of Agriculture, Faculty of Agriculture, University of Brawijaya, Malang and Lecturer, \\ Faculty of Agriculture, Merdeka University, Ponorogo, East Java, INDONESIA \\ ${ }^{2}$ Faculty of Agriculture, University of Brawijaya, Malang, East Java, Indonesia \\ ${ }^{3}$ Research Center for Peanuts-Cassava \& Related Species, Malang East Java, INDONESIA
}

\begin{abstract}
Soybean is one of the important crop in Indonesia. The study aimed to identify the number and the roles of CPMMV (Cowpea Mild Mottle Virus) disease resistance genes on soybean crop genes and its inheritance traits. The Gumitir and Argopuro soybean varieties were used as susceptible female parents $(P 1)$. The MLG 0120 and MLG 0278 genotypes were used as resistant male parents $(P 2)$. The $F_{1}, F_{1 . r}, F_{2}, B C_{1.1}, B C_{1 \cdot 2}$ was examined for genes number and its actions. The study applied Randomized Complete Block Design with three replications. Seeds were produced from the cross of resistant and susceptible parents $\left(F_{1}\right)$, mating between $F_{1}\left(F_{2}\right)$, and Backcross $\left(B C_{1.1}, B C_{1 \cdot 2 .}\right)$, and male-female parents $\left(P_{1}\right.$ and $\left.P_{2}\right)$ which were mechanically inoculated by CPMMV isolate. The result confirmed that the resistance properties of soybean derived from the cross series of Gumitir x MLG 0120 and Argopuro x MLG 0120 were controlled by two duplicate recessive epistatic genes and its inheritance was additive. In cross series of Argopuro x MLG 0278 and Gumitir x MLG 0278 , however, the resistance was controlled by two duplicate dominant epistatic genes and its inheritance was additive.
\end{abstract}

Keywords: resistance gene, soybean, disease of Cowpea Mild Mottle Virus

\section{Introduction}

Soybeans is the most important commodity after paddy and corns since fresh soybeans are required in food industry and soybean cake, as well as feed industry [1]. There are two types of soybean as the main protein sources for Indonesians, namely Glycine max (yellow soybean) and Glycine soja (black soybean). The improvement of soybean productivity encounters problems regarding pests and diseases. It is particularly relevant with the global policy and Indonesian governmental effort to increase soybean yield production. Cowpea Mild Mottle Virus (CPMMV) disease is one of the major disease which often cuts the soybean production [2] [3] [4].

CPMMV is one of main diseases in soybean crop [5]. It was firstly reported when it infected cowpea crop in Ghana [6]. In Indonesia, its existence was firstly recorded in 1984 when it was found on soybean crops in Java [7], and the next study shows that the virus also infects peanut [8] [9]. Currently, CPMMV has been spreading in the production center of soybean crop and becoming a constraint in improving soybean production. In East Java, CPMMV has affected almost all soybean crops up to $100 \%$ and these diseases decrease soybean yield significantly [10]. Its massive attack is triggered by the rise of whitefly vector insect population [10] [11]. CPMMV infection can instigate a loss between 11-56\% [12].

Pesticide often used to control pests and diseases. Spraying is administered during the life cycle of plants within the interval of 3-10 days for each spraying [13]. However, there has been no pesticide to control the virus yet. Administering insecticide aimed to control insect vector is in fact not effective since it contaminates environment and its residues remain in harvest. The negative impact of chemical pesticed has been repoted from numerous countries. The application of chemical pesticides has been restricted in many developing countries, including Indonesia. New attempt to increase soybean production therefore becomes crucial. Due to these reasons, planting varieties which resist to pests and diseases becomes the important strategy.

Improving a CPMMV-resistant soybean variety is an alternative way to advance and encourage its production. It has been reported in numerous countries [14]. Planting such soybean variety is also the most effective and efficient means to control CPMMV disease. Combining CPMMV-resistant soybean varieties needs basic information about a pattern of resistance inheritance against CPMMV. Genetic engineering of numerous plants nowadays become the significant issues to produce plants cultivars with high yield, tolerant to drought, and resistant to pest and diseases. Some necessary parameters of the crops with resistance to pest and diseases are the number and the role of genes. The information plays an important role and becomes the basic requirement to implement a program of resistance breeding against CPMMV disease. 
The study aimed to identify the number and its actions in the resistance properties of soybean crops against CPMMV. The collected information is expected to be beneficial for breeders in order to combine potential varieties which resist CPMMV.

\section{Methodology}

The study was conducted in Research Center for Peanuts-Cassava \& Related Species, Malang East Java (BALITKABI-Malang) and field experiment was done at Madiun started from July 2010 to December 2012. CPMMV isolation was performed in the Laboratory of Agriculture Faculty, Merdeka University, Ponorogo, East Java. Establishing the base population of reciprocal $\mathrm{F}_{1}, \mathrm{~F}_{1}, \mathrm{~F}_{2}, \mathrm{BC}_{1.1}$ and $\mathrm{BC}_{1 \cdot 2}$ had been accomplished during August 2010-February 2011. The study on estimation of number and the role of resistance genes of $\mathrm{P}_{1}, \mathrm{P}_{2}, \mathrm{~F}_{1}, \mathrm{~F}_{2}, \mathrm{BC}_{1.1}, \mathrm{BC}_{1.2}$ against CPMMV virus had been carried out during August-December 2012 on agricultural field in Madiun.

Materials of study involved Agropuro and Gumitir soybean varieties as the susceptible female parents (P1) and of MLG 0120 and MLG 0278 genotypes (P2) as the resistant male parents against CPMMV (Fig.1). These genotypes were resulted from Balitkabi's germ plasma screening [13]. The population of $\mathrm{F}_{1}, \mathrm{~F}_{2}, \mathrm{BC}_{1.1}$, $\mathrm{BC}_{1.2}$ were also involved in the genetic traits assessment. In order to control plant population in the field, some materials included Nitrogen-Phosphor-Potassium fertilizer, compost which are derived from farmyard manure, Marshall Insecticide, Deltametrin 2.5 EC, plastic bags, plastic pots, sprayer, forceps, Petri dish, a scale and CPMMV isolates from Balitkabi Malang.

CPMMV was isolated and maintained in infected soybean crop. The isolation was done in laboratory with standard methods. The isolation was performed by obtaining 1 gram of soybean crop's leaves affected by CPMMV. Leaves were mashed and dissolved in $9 \mathrm{ml}$ of phosphate buffer solution with $\mathrm{pH}$ 7.2. [15]. The extract of soybean leaves was collected for further analysis.

Six populations, namely $\mathrm{P}_{1}, \mathrm{P}_{2}, \mathrm{~F}_{1}, \mathrm{~F}_{2}, \mathrm{BC}_{1.1 .1}$ and $\mathrm{BC}_{\text {.1.2. }}$ were tested to identify the number and the role of resistance genes against the disease of CPMMV. These populations were grown in filed and in 7 days after planting were inoculated by CPMMV. $\mathrm{P}_{1}, \mathrm{P}_{2}, \mathrm{~F}_{1}, \mathrm{BC}_{1.11}$ and $\mathrm{BC}_{.1 .2}$ consisted of at least 20 plants respectively, while $\mathrm{F}_{2}$ population consisted of 300 plants in order to equal the variation of segregation generation [16] [17] [18]. It was performed to allow proper observation on the population resistance against CPMMV, mainly in $\mathrm{F}_{2}$. The field study was completed by Randomized Complete Block Design with three replications. The observable parameter was the intensity of disease visually done by observing each plant on day 35 after inoculation.
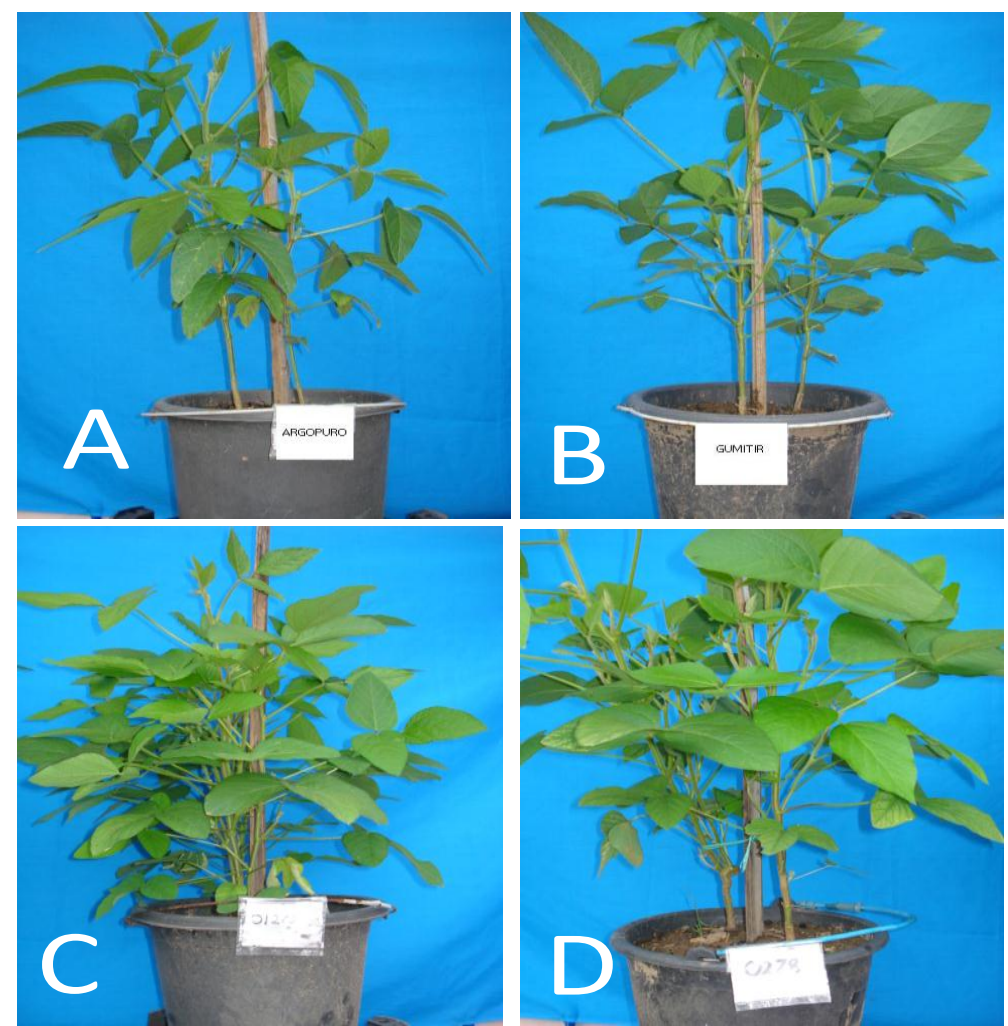

Fig. 1. The soybean varieties for experiment. The susceptible female consists of varieties Argopuro (A) and Gumitir (B), and the resistant male parents against CPMMV consist of MLG0120 (C) and MLG0278 (D). 
The number of genes was analyzed by segregation analysis in $\mathrm{F}_{2}$ population to presume the number of controlling genes for resistance properties against CPMMV disease. Chi-square $\left(\chi^{2}\right)$ analysis was performed for 2 classes, namely: resistant and susceptible; three classes, namely: resistant, moderately resistant, and susceptible; also four classes, namely: resistant, moderately resistant, moderately susceptible and susceptible. The analysis compares the number of observation and the expectation [19] [20].

$$
\chi^{2}=\sum_{i=1}^{n} \frac{\sum\left(O_{i}-E_{i}\right)^{2}}{E_{i}}
$$

where: $\mathrm{O}_{\mathrm{i}}=$ total of $\mathrm{i}^{\text {th }}$ - phenotype based on observation result

$\mathrm{E}_{\mathrm{i}}=$ total of expected phenotype

The role of genes was analyzed by the average of generation to presume whether the model of resistance gene was additive or dominant. To identify the gene interaction, a scale test according to Mather and Jinks (1982) was administered based on the average component calculation of four, six, and three-parameter model generations.

\section{Number of resistance genes}

\section{Result And Discussion}

Segregation analysis was performed in $\mathrm{F}_{2}$ population to presume the number of controlling genes for resistance properties against CPMMV disease. The result of chi-square analysis in $\mathrm{F}_{2}$ having match ratio of Argopuro x MLG 0120 and Gumitir x MLG 0120 was 9:7 in which the probability score was 30-50\% and 70$90 \%$, respectively. By the ratio 9:7 in $\mathrm{F}_{2}$, it implied that the resistance properties against CPMMV were controlled by two genes reacting to duplicate recessive epistasis. In such condition, the recessive homozygous gene in one locus was epistatic toward the dominant gene in another locus. Based on the description, it could be assumed the soybean crop would possess the resistance properties against CPMMV if it had dominant $\mathrm{T}$ and $R$ genes ( $T_{-} R_{-}$) altogether. When there was only the existence of one dominant gene ( $T_{-} r r$ or $t$ t $\left.R_{-}\right)$or recessive homozygote (ttrr), however, the crop would be susceptible against CPMMV disease (Fig. 2).

It is similar with Crowder (1993) who provides examples of flower color in peas in which C gene is dominant in color formation and $\mathrm{P}$ gene is dominant in forming purple pigment [19]. When an individual has a genetic arrangement of $\mathrm{C}_{-} \mathrm{pp}, \mathrm{ccP} \mathrm{P}_{-}$or ccpp, the appearing genotype is a flower with white color. The existence of two dominant genes altogether is complementary. Recessive genes in homozygous condition are not active and are epistatic against dominant genes $(c=p)>$ C,P. In other research, Ramires (1991) explains that theoretically the match ratio is $9: 7$ which means $9 / 16$ part of all population is resistant and the remaining $7 / 16$ is susceptible [21].

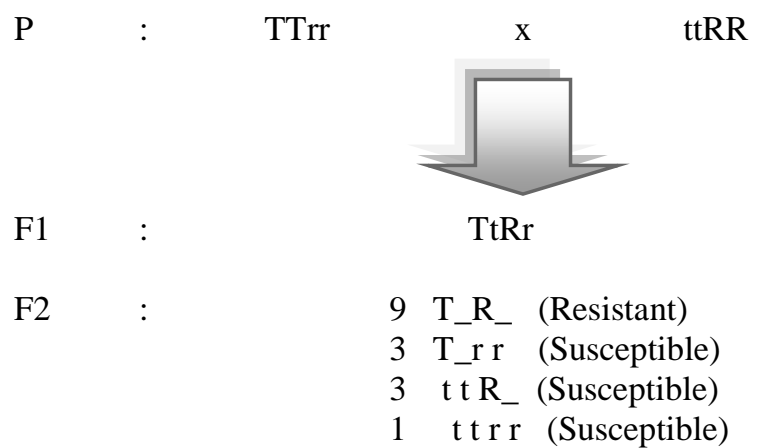

\section{Resistant : $\quad$ Susceptible

$9 \quad: \quad 7$

Fig.2. An illustration of double recessive epistasis inheriting resistance properties against CPMMV disease on soybean crop

The expression of double recessive gene could induce interaction between genes. Hence, the analysis was necessarily continued to the scale test and the analysis of gene's role based on the component calculation of average generation. The probability value of $5 \%$ was considered as a demarcation line whether a match ratio or inheritance pattern was accepted or rejected from crossed pairs. 
Meanwhile, the cross series of Argopuro x MLG 0278 and Gumitir x MLG 0278 had a match ratio of $15: 1$ where the probability value was $50-70 \%$ and $10-20 \%$, respectively (Table 1 ). Theoretically, the match ratio of 15:1 implies that $15 / 16$ part of all population is resistant and the remaining 1/16 is susceptible. In the segregation pattern, resistance property controlling genes consist of two genes functioning under duplicate dominant epistasis [22].

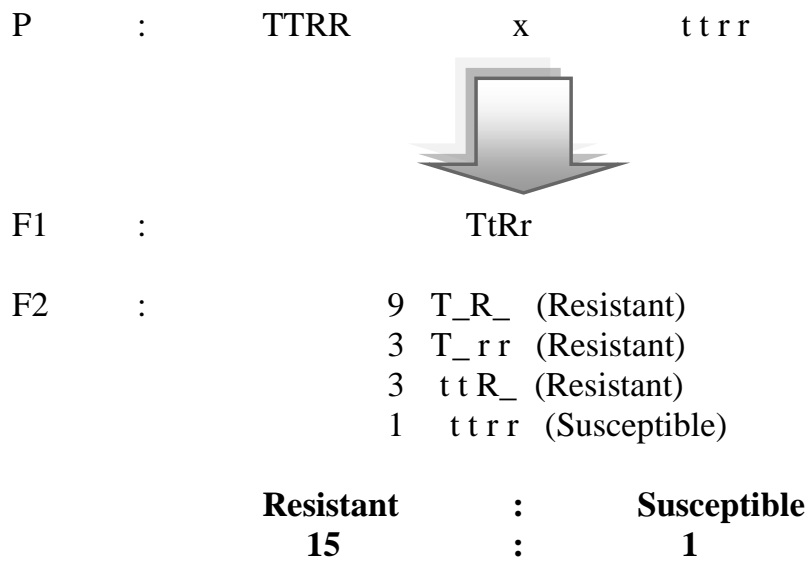

Fig. 3. An illustration of double dominant epistasis inheriting resistance properties against CPMMV disease on soybean crop

Table 1. Values of chi-square $\left(\chi^{2}\right)$ and degrees of segregation match ratio in $\mathrm{F} 2$

\begin{tabular}{|c|c|c|c|l|}
\hline Group F2 & Match ratio & $\chi^{2}$ & Probability (\%) & \multicolumn{1}{|c|}{ Resistance controlling genes } \\
\hline Argopuro / MLG 0120 & $9: 7$ & $0.84 \mathrm{~ns}$ & $30-50$ & $\begin{array}{l}\text { Two duplicate recessive epistatic } \\
\text { genes }\end{array}$ \\
\hline Gumitir / MLG 0120 & $9: 7$ & $0.03 \mathrm{~ns}$ & $70-90$ & $\begin{array}{l}\text { Two duplicate recessive epistatic } \\
\text { genes }\end{array}$ \\
\hline Argopuro / MLG 0278 & $15: 1$ & $0.38 \mathrm{~ns}$ & $50-70$ & $\begin{array}{l}\text { Two duplicate dominant epistatic } \\
\text { genes }\end{array}$ \\
\hline Gumitir / MLG 0278 & $15: 1$ & $1.86 \mathrm{~ns}$ & $10-20$ & $\begin{array}{l}\text { Two duplicate dominant epistatic } \\
\text { genes }\end{array}$ \\
\hline
\end{tabular}

Ns. Not significant

By the match ratio of 15:1, it could be explained that the resistance properties were controlled by a pair of dominant-recessive alleles within two genes on different loci. The resistance properties would emerge when there was a dominant allele either in one or both loci. Based on those descriptions, it could be assumed that soybean crop would have resistance properties against CPMMV when it had dominant $\mathrm{T}$ and $\mathrm{R}$ genes altogether ( $\left.T_{-} R_{-}\right)$, or only one dominant gene ( $T_{-}$rr or $\left.t t R_{-}\right)$. In contrast, the existence of recessive homozygous gene (ttrr) created crop susceptible against CPMMV disease (Fig. 3).

\section{Genes actions of resistance genes}

Based on the result, it was established that there was more than one gene having a significant role. The analysis therefore was continued to the scale test in order to recognize whether there was gene interaction. The result of scale test with four parameters revealed that four series of crosses had 3 parameters whose score was $\leq$ 0 , meaning there was no non-allele gene interaction in the pairs. According to scholars, when the result of test indicates no interaction between non-allele genes, the estimation of average genetic parameter uses three parameters, namely mean or average (m), additive influence (d), dominant influence (h) [16] [23].

Based on the estimation of three genetic parameters (Table 2), only one real parameter displayed the role of additive gene (d) in four series of crosses. It revealed that the resistance properties in the crosses of Argopuro and MLG 0120, Gumitir and MLG 0120 were controlled by double recessive gene which reacted additively. Meanwhile, the crosses of Argopuro and Gumitir with MLG 0278 was controlled by two genes which were duplicate dominant epistatic and they reacted additively. 
Table 2. The scale test on disease intensity of Cowpea mild mottle virus in four series of crosses

\begin{tabular}{|c|c|c|c|}
\hline Series of crosses & Genetic parameter & Score & Calculated t value \\
\hline \multirow{4}{*}{ Argopuro X MLG 0120 } & $\mathrm{m}$ & 0.051 & 0.059 \\
\cline { 2 - 4 } & $\mathrm{d}$ & -0.190 & $-4.521 * *$ \\
\cline { 2 - 4 } & $\mathrm{h}$ & 0.261 & 0.006 \\
\hline \multirow{4}{*}{ Argopuro X MLG 0278 } & $\mathrm{m}$ & 0.857 & 1.675 \\
\cline { 2 - 4 } & $\mathrm{d}$ & -0.175 & $-5.324 * *$ \\
\cline { 2 - 4 } & $\mathrm{h}$ & 1.455 & 0.031 \\
\hline \multirow{3}{*}{ Gumitir X MLG 0120 } & $\mathrm{m}$ & -0.003 & 0.005 \\
\cline { 2 - 4 } & $\mathrm{d}$ & 0.088 & -2.040 \\
\cline { 2 - 4 } & $\mathrm{h}$ & 0.808 & 0.002 \\
\hline \multirow{3}{*}{ Gumitir X MLG 0278 } & $\mathrm{m}$ & -0.074 & 1.715 \\
\cline { 2 - 4 } & $\mathrm{d}$ & 1.210 & $-2.127 *$ \\
\cline { 2 - 4 }
\end{tabular}

Significant level: $* \mathrm{P}<0.05 ; * * \mathrm{P}<0.01$

The role of additive gene is indeed significant in determining the similarity of traits between parents and their offspring. The influence of additive gene exposes a genotype value of an affected trait. When a trait is determined by an influence of additive gene, the trait has high genetic value and will be very beneficial for breeding programs of soybean crop. The influence of additive genes can be inherited, while the influence of non-additive genes is not inherited [24] [25].

\section{Conclusion}

The result confirmed cross series of MLG 0120 genotype as the resistant male parent; thus, the inheritance of resistance against CPMMV disease was controlled by two duplicate recessive epistasis genes and was additive. Meanwhile, in the cross series of MLG 0278 genotype as the resistant male parent, the inheritance was controlled by two duplicate dominant epistasis genes and was additive.

\section{Acknowledgements}

The author would like to thank General Director of Higher Education (DIKTI) for the grant of Doctoral program scholarship, the Head of Balitkabi Malang for the seed contribution, and those who provided direct and indirect assistance.

\section{References}

[1] M.A. Marchant, C. Fang, B. Song, Issues on adoption, import regulations, and policies for biotech commodities in China with a focus on soybeans, Agrobiotechnology Management and Economics, 2002.

[2] E.A.Grabau, W.H. Davis, N.D. Phelps, B.G. Gengenbach, Classification of soybean cultivars based on mitochondrial DNA restriction fragment length polymorphisms. Crop science, 32(1), 1992, 271-274.

[3] I.G. Laguna, J.D. Arneodo, P. Rodríguez-Pardina, M Fiorona, Cowpea mild mottle virus infecting soybean crops in northwestern Argentina. Fitopatologia Brasileira, 31(3), 2006, 317-317.

[4] S. Nuryanti, R. Kustiari, Meningkatkan kesejahteraan petani kedelai dengan kebijakan tarif optimal. Pusat Analisis Sosial Ekonomi dan Kebijakan Pertanian, Bogor, 2007.

[5] N.M. Horn, N. Saleh, Y. Baliadi, Cowpea mild mottle virus could not be detected by ELISA in soybean and groundnut seeds in Indonesia. Neth. J. Pl. Path. 97, 1991, 125-127.

[6] A.A. Brunt, R.H. Kenten. Cowpea mild mottle, a newly recognized virus infecting cowpeas (Vigna unguiculata) in Ghana. Ann. Appl. Biol. 74, 1973, 67-74.

[7] N.R. Iizuka, D.V.R. Rajeshwari, T. Reddy, V. Goto, N. Muniyappa, N. Bharathan, A.M. Ghanekar. Natural occurrence a strain of cowpea mild mottle virus on groundnut (Arachis hypogaea) in India. Phytopath. Zeitschrift, 109, 1984, 245- 253.

[8] M. Iwaki, P. Thongmeearkom, Y. Honda, M. Prommin, N. Deema, T. Hibi, N. Iizuka, C.A. Ong, N. Saleh, Cowpea mild mottle virus occuring on soybean and peanut in Southeast Asian countries. Tech. Bull. Trop. Agr. Res. Centr. Japan 21, 1986, 187-120.

[9] N. Saleh, Y. Baliadi, N. Horn. Cowpea mild mottle virus isolated from naturally infected Arachis hypogaea L. Penelitian Palawija 4(1), 1989, 32-35.

[10] N. lizuka, M. Roechan, K. Matsumoto. Report on the virus diseases of soybean in Indonesia from August 22 to October 21, 1984. $1-9$.

[11] Y. Baliadi, N. Saleh. Virus-virus utama kedelai di sentra produksi kedelai Jawa Timur. Dalam Meningkatkan Peranan Perhimpunan Fitopatologi Indonesia Menuju Pertanian yang Maju, Efisien dan Tangguh (I.G.P. Dwidjaputra, N. Westen, dan I.B Oka. Eds.). Pros Kongres Nasional X dan Seminar Ilmiah Perhimpunan Fitopatologi Indonesia. 1989, 100-103.

[12] H.M. Akin, Respon Beberapa Genotipe Kedelai terhadap CPMMV (Cowpea Mild Mottle Virus). Jurnal Hama dan Penyakit Tanaman Tropika, 3(2), 2003, 40-42.

[13] H. Kuswantoro, S. Zubaidah, N. Saleh, Keragaan Genotipe Kedelai Lokal Jawa Timur Terhadap Serangan CPMMV. Inovasi teknologi kacang-kacangan dan umbi-umbian mendukung kemandirian pangan \& kecukupan energy, 2006, 73 - 81.

[14] J. Huang, S. Rozelle, C. Pray, Q. Wang, Plant biotechnology in China. Science, 295(5555), 2002, 674-676.

[15] N. Saleh, H. Muslikul. Kehilangan Hasil Koro Pedang (Canavalia gladiate) Akibat Infeksi Cowpea Mild Mottle Virus. Inovasi teknologi kacang-kacangan dan umbi-umbian mendukung kemandirian pangan dan kecukupan energy, 2006, 380 - 385 .

[16] K. Mather, J.L. Jinks, Biometrical Genetics. $3^{\text {rd }}$ ed. (University Press, Cambridge, 1982)

[17] Kuswanto. 2002. Pendugaan Parameter Genetik Ketahanan Kacang Panjang (Vigna sesquipedalis L. Fruwith). Desertasi. Universitas Brawijaya Malang.

[18] D. Roy. Biometrical Genetics: Analysis of quantitative variation (Alpha Science, Intl Ltd, 2012) 
[19] L.V. Crowder, Genetika tumbuhan (Gadjah Mada University Press, Yogyakarta1993).

[20] G. Achquaah, Principles of plants genetics and breeding, (Wiley-Blackwell; 2 edition, 2012).

[21] D.A. Ramires, Genetics. 7th ed. (Seameo Searca. University of the Philippines at Los Banos, 1991).

[22] G.A. Reid, The Principles of Heredity, (BiblioBazaar, Charleston, South Carolina, 2009).

[23] R.K. Singh, B.D. Chaudhary, Biometrical Methods In Quantitative Genetic Analysis. (Kalyani Publ., Ludhiana, New Delhi,1979)

[24] G. Hayward, Applied Genetics (Macmillan Education Ltd, Hampshire. 1990).

[25] B.C. Lamb, The Applied genetics of Plants, Animal, Human and Fungi (World Scientific Publishing Company, Singapore, 2000). 